\title{
東京農工大学工学部有機材料化学科 機能材料プロセス講座オープンラボ 斎藤拓研究室
}

\section{1.はじめに}

東京農工大学工学部は中央線の東小金井駅（東京駅から 約 35 分）で下車, 徒歩 8 分という交通の便のよい場所に あり，その利便性が民間企業との共同研究や交流に生かさ れている. 本学には民間企業との共同研究を推進させるた めの「共同研究開発センター」やベンチャービジネスのシー ズとなる独創的な研究を行う「ベンチャービジネスラボ」, さらには研究室の有するシーズと民間企業のニーズをマッ チングさせる「リエゾン・コーディネーター制度」があり， 産学連携活動に積極的に取り組んでいる. 工学部有機材料 化学科では化学合成や高分子物性などの基礎研究から光・ 電子機能材料などの応用研究に至る個性的かつ幅広い研究 を行っており，数多くの企業と様々な分野で連携している.

$$
\text { 2.オープンラボ }
$$

大学の門を入り欅並木, 銀杏並木, 桜並木を歩くと有機 材料化学科のある 5 階建ての 4 号館にたどり着く. その 4 階に, 面積が約 $400 \mathrm{~m}^{2}$ の機能材料プロセス講座オープン ラボがこの 7 月に完成した. オープンラボには市原祥次教 授, 村瀬繁満教授, 斎藤拓助教授の 3 つの研究室が入って いる. 各研究室は独立して研究を行っているが, 各々が所 有している実験装置はラボ内の共通の実験室に設置されて いる. 実験室は物理実験室, 化学実験室, 成形加工室, 機 器室から成る. 温調の必要な機器室以外の廊下側にはドア や壁がなく, 学生たちが実験している様子を遠くからでも 見ることができる. また, 学生室にはドアがなく, 研究室 間の交流がしやすくなっている，市原研究室では $20 \mathrm{~mm}$ 押出成形装置や DSC 等によりフィルムの成形や熱分析な ど, 村瀬研究室では溶融紡糸装置により作製された緎維の 構造解析などに関する研究を行っている.

\section{3. 主な研究テーマ}

斎藤研究室は 1999 年 9 月に筆者が東工大から農工大へ 異動して以来, ゼロからスタートした新しい研究室である. 本研究室は「CCD カメラ装着型光散乱測定装置」, 「光電

* Saito, Hiromu

東京農工大学 有機材料化学科

東京都小金井市中町 2-24-16 ( T 184-8588)

2001.9.1 受理
子増倍管装着型光散乱測定装置」,「光変調素子装着型応 力一複屈折同時測定装置」「「デジタルカメラ装着型光学 . 偏光顕微鏡（オリンパス）」,「長焦点デジタル顕微鏡（ハ イロックス)」, 「超臨界場発生システム 2 台 (50 MPa 用 耐圧容器 1 台, $20 \mathrm{MPa}$ 用耐圧容器 3 台) (耐圧硝子)」, 「超 臨界場観察用耐圧容器 (耐圧硝子)」, 「小型混練射出成形 装置」,「誘電緩和測定装置（ソーラートロン）」,「UV ス ペクトル測定装置（日本分光）」,「走査型電子顕微鏡（日 立)」，「イメージングプレート装着型広角 X 線回折測定装 置（リガク）」を所有しており，それらの装置をフル稼働 させて, 修士学生 8 人と学部学生 6 人と共に「ポリマーブ レンド」,「非晶構造」,「結晶化」,「超臨界」の 4 つのテー マを柱に研究室の土台作りを行っている.

\section{1 ポリマーブレンド}

ポリマーブレンドの研究には主として CCD カメラ装着 型光散乱測定装置を利用している. 本研究室の光散乱測定 装置により, 二次元光散乱像が $3 \mathrm{~s}$ 間隔, 一次元光散乱強 度分布が $0.2 \mathrm{~s}$ 間隔で高速時分割測定できる. また，コン ピューター自動制御可能な偏光板回転装置を装着している ので, $\mathrm{Vv}$ (偏光子と検光子の偏光方向が平行) 光散乱と $\mathrm{Hv}$ (偏光子と検光子の偏光方向が垂直) 光散乱を $0.3 \mathrm{~s}$ 間 隔で交互に測定できる.Vv 光散乱から液々相分離による 密度摇らぎ, $H v$ 光散乱から結晶化による光学異方性に関 する知見が得られるので, $\mathrm{Vv}$ 光散乱と $\mathrm{Hv}$ 光散乱の交互 連続測定により，それらの分離評価が可能である.

非晶性高分子として知られているポリカーボネート （PC）にポリエチレンオキサイド（PEO）をブレンドする ことで, PCがわずか数十秒で結晶化することを $\mathrm{Hv}$ 光散 乱および偏光顕微鏡観察により見出している. $\mathrm{PC} / \mathrm{PEO}$ ブレンドは温度上昇に伴い一相 $\rightarrow$ 二相 $\rightarrow 一$ 相へと相転移す るループ型の相図を有し，その二相域でのみ結晶化する. また, その結晶化はスピノーダル分解と競争的に生じるこ とを明らかにしている. 臨界点近傍ではスピノーダル分解 と結晶化の競争により, 相互連結構造の PC リッチ相に 沿って数珠状球晶が形成される（図 1). PC/PEO ブレン ド以外でも, ポリエチレンテレフタレートやポリエチレン ナフタレートにポリトリメチレンテレフタレートをブレン ドすることで, 結晶化速度が数倍から数十倍も速くなるこ とを見出している．ブレンドにおける結晶化の誘発や加速 はスピノーダル分解中の up-hill 拡散を介した結晶核形成 
頻度の増加による。スピノーダル分解と結晶化が競争的に 進行することは, $\mathrm{Vv}$ 光散乱と Hv 光散乱の交互連続測定 により得られる密度摇らぎと光学異方性の分離評価の結果 から考察している。

ポリマーブレンドの液々相分離と界面でのイオン偏析を 利用して，ポリマーコロイドのコアーシェル構造の制御を 試みている。例えば, ポリビニルアルコール/水/塩ブレン ドは，低温で相溶するが高温で液々相分離する下限臨界共 溶温度（LCST）型の相図を有する。それを一相域から二 相域に温度ジャンプさせると，スピノーダル分解による 液々相分離が生じて, その後の相構造の界面でのイオン偏 析により相分離が停止する．液々相分離とイオン偏析の速 度論的な違いにより, 球形から連結構造に至る多様な形体 のコアーシェル構造を得ている.

二相系ポリマーブレンドの $\mathrm{PC} /$ 変性ポリメタクリル酸 メチル（変性 PMMA）ブレンドを延伸すると, 偏光分離 特性が得られる. 偏光分離特性の発現は延伸方向とそれに 垂直な方向の相間での屈折率差の違いによる。このような 相間での屈折率差の方向依存性を有する二相系試料では四 つ葉のクローバー型の Hv 光散乱像が出現して (図 2), その散乱像の解析により相間での屈折率差の方向依存性を 論じることができる. 光散乱用加熱延伸器を利用した高温 延伸中の光散乱像の追跡結果から屈折率差の知見を得て, 偏光分離特性を得るための最適条件を探索している.

二相系ポリマーブレンドの $\mathrm{PC} /$ ポリメタクリル酸メチ ル (PMMA) ブレンドを延伸すると球形からフィブリル 状へと相分離構造が変化して, 白色からパール光沢へと光 学特性が変化する.このような相構造の変化機構や相構造

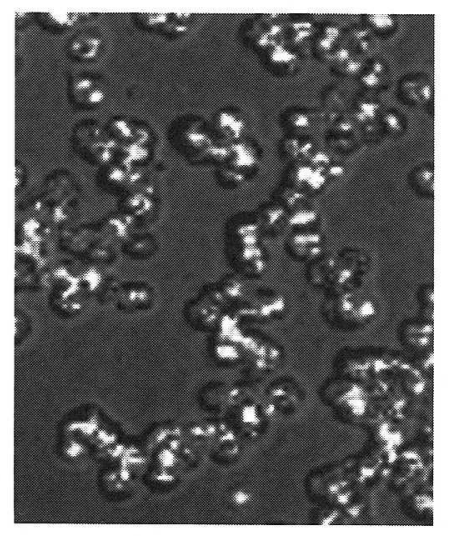

図 1 PC/PEO 系における数珠状結晶

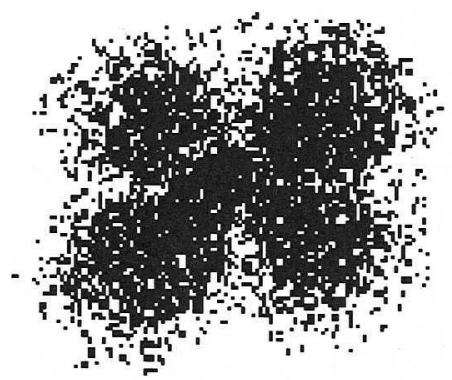

図 2 非晶性の二相系ポリマーブレンドを延伸して得られ る $\mathrm{Hv}$ 光散乱像
と光学特性との関係を明らかにするために，熱延伸に伴う 相構造変化の光散乱等による追跡や, 透過 · 反射光強度の 波長依存性に関するUV スペクトル測定を試みている。

\section{2 非晶構造}

本研究室の応力一複屈折同時測定装置（図 3）により, フィルム試料の一軸延伸中, 応力緩和中, クリープ中の応 力と複屈折を $0.1 \mathrm{~s}$ 問隔で同時に測定できる。これらの測 定結果から高分子の変形機構, 分子運動, コンホメーショ ンなどに関する基礎科学的知見が得られる。また，光変調 素子の利用により数 nm という小さな retardation も検出 できるので，低複屈折光学ディスク基盤材料の光学特性の 評価にも用いることができる。

一般に，応力緩和過程において「ガラス転移領域」と「ゴ ム状平坦領域」の間に屈曲が現れる。ところが，複屈折緩 和過程において，PMMA ではそれぞれの領域間に屈曲が 現れるのに対して，PCでは屈曲が現れない。両者の複屈 折緩和挙動の大きな違いはガラス領域における変形機構の 違いによる。応力緩和と複屈折緩和の重ね合わせ曲線を Kohlrausch-Williams-Watts (KWW) 式と修正ラウス式で カーブフィットすることにより「ひずみ」成分と「配向」 成分への分離評価が可能になる。延性材料の PCでは「配 向」成分の分率が高く，ぜい性材料の PMMA では「ひず み」成分の分率が高いことを明らかにしている。

側鎖にフェニル基を有するポリスチレン系のポリマーを ガラス転移温度以下のガラス状態で一軸延伸すると，延伸 に伴い複屈折が正から負へと変化することを見出している。 また，ガラス状態での応力緩和中の複屈折が正から負へと 変化することも見出している（図 4)。これらの結果は応 力緩和中あるいは一軸延伸中の応力と複屈折の比が一定に なるという光弾性則からの背異を意味し，それは応力緩和 あるいは延伸中のフェニル基のコンホメーション変化によ る.コンホメーション変化が $\mathrm{KWW}$ 型の関数で表される 緩和過程で，その緩和時間が $0.03 \mathrm{~s}$ と極めて長く，従来 知られている $\beta$ 緩和とは異なることを明らかにしている. 非晶の分子運動の評価に誘電緩和測定も利用している. 一相系ポリマーブレンドの PMMA/ポリフッ化ビニリデ ン (PVDF) ブレンドにおける誘電損失の周波数依存性の Havriliak-Negami 式による解析から得られる緩和時間が 熱処理時間に伴い長くなることから，熱処理に伴い秩序性 の増加することが示唆された．この解析法の応用として, プラスチック成形品のような分子配向あるいは結晶化した

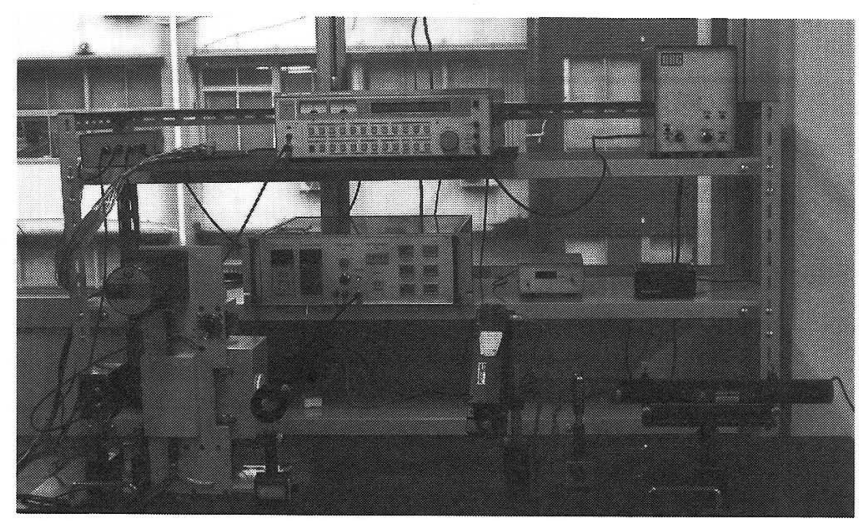

図 3 応力一複屈折同時測定装置 
試料における非晶構造の評価が今後の課題である.

非晶構造の直接的な評価には微弱な散乱光を検出可能な 光電子増倍管型光散乱測定装置を用いている. 一相系ポリ マーブレンドにおける $\mathrm{Hv}$ 光散乱強度が二乗平均光学異方 性の加成値よりも大きく, それが温度の上昇に伴い低下す ることから，水素結合的な相互作用による局所的な秩序構 造の形成が示唆された。 また, 高分子ガラスの physical aging に伴い Vv 散乱強度が増大することから agingに伴う 密度摇らぎの増加が示唆された。

\section{3 結晶化}

結晶性ポリマーのブレンドや熱処理の違いによるナノ メートル次元（例えばラメラ晶）の高次構造制御を試みて いる，例えば，線状低密度ポリエチレン（LLDPE）を高 温で等温結晶化させた後に降温させると既存の厚いラメラ 晶の間に熱的に不安定な薄いラメラ晶が連続的に形成され, それに伴い Hv 光散乱強度は増加する. LLDPEに高密度 ポリエチレン（HDPE）をブレンドして高温で結晶化させ ると, 降温中の LLDPE ラメラ晶の形成が抑制されて, 光 散乱強度の増加する温度域が低温側まで広くなることを見 出している. それはラメラスタック間非晶領域中に存在す る HDPE 鎖が LLDPEラメラ晶の成長を抑制しているた めと考えられる。それに対して, LLDPE/HDPE ブレンド を低温で結晶化させると, 降温中に HDPE ラメラ間非晶 領域に新たにLLDPEラメラ晶が規則正しく形成された後 にLLDPEラメラ間非晶領域に LLDPEラメラ晶が不規則 に形成されることで, 光散乱強度が降温中に増加した後に 低下することも見出している.

光散乱を利用して配向結晶化挙動も調べている。ポリエ チレンナフタレート（PEN）を熱延伸すると, 低延伸で は円形の $\mathrm{Hv}$ 光散乱像が現れるのに対して, 高延伸では広 角側のロッド状散乱像と小角側のストリークが重なった八 つ葉状の散乱像が見出された。 それらの光散乱像に対する 修正 Hosemann 式による解析により（図 5), 低延伸では 微結晶がランダムに配列しているが, 高延伸で板状結晶の 積層体が形成されて, 延伸比の増加に伴い積層体中の板状 結晶の数とサイズが増加して板状結晶間距離は短くなり, さらには積層体の配向度が高くなることを明らかにしてい る. 応力測定可能な熱延伸器を利用した冷延伸あるいは溶

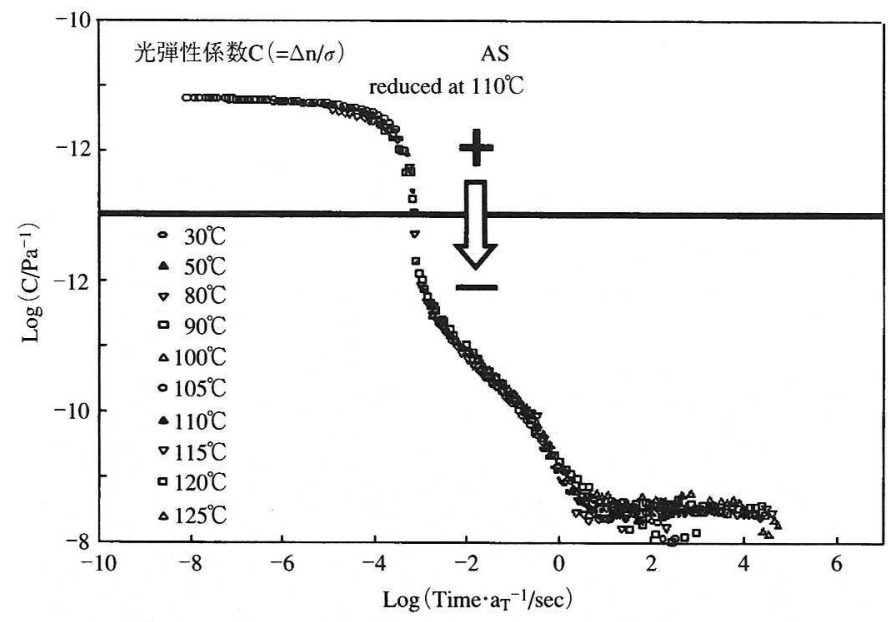

図 4 ポリスチレン系ポリマーの応力緩和中における複屈 折緩和挙動
融せん断中の $\mathrm{Hv}$ 光散乱像の追跡結果から得られる応力一 ひずみ挙動と高次構造形成の関係を調べている。

液晶性ポリエステルを溶融状態から温度ドロップして熱 処理すると, 単一のポリマーであるにもかかわらずスピ ノーダル分解による液々相分離が生じて, 液晶相と非晶相 の相互連結構造が形成されることを見出している．相互連 結構造の形成に伴い, 液晶構造の形成は途中で止まる。こ のような特異な高次構造形成は剛直分子鎖の排除体積効果 によると考えられ，それを利用した高強度材料等の設計や 結晶性ポリエステルとのブレンドが今後の課題である.

\section{4 超臨界}

上述のポリマーブレンドや結晶化などに関する基礎的な 知識を活かして, ポリマーに超臨界流体を含浸させること によるポリマーの高次構造制御を試みている。本研究室で は超臨界場観察用耐圧容器と長焦点デジタル顕微鏡あるい は CCD カメラ装着型光散乱测定装置を組み合わせた，「超 臨界顕微鏡システム」あるいは「超臨界光散乱システム」 を利用して, 超臨界雲囲気下での結晶高次構造や多孔構造 の形成過程を in-situに追跡している.

ポリプロピレン（PP）を超臨界 $\mathrm{CO}_{2}$ 雲囲気下で結晶化 させることで, ドメイン内に一方向の光学異方性を有する モザイク構造が形成されることを見出した。.モザイク構造 を TEM 観察したところ, 厚さ数十 $\mathrm{nm}$ のラメラ晶が数 $\mu$ $\mathrm{m}$ の長さにわたって規則正しく平行に配列していること が明らかになった。また，その融点が大気圧下で得られる ものに対して $10^{\circ} \mathrm{C}$ 以上も高く, 融解ピークが極めて狭く なることから，厚さが均一で厚いラメラ晶が形成されてい ることが示唆された。このような液晶性ポリマーに特有な 高次構造が柔軟性ポリマーであるPPにおいて形成される ことは, 超臨界 $\mathrm{CO}_{2}$ 雾囲気下で PP の分子鎖が剛直な溶融 構造を有することによると考えられる。

$\mathrm{PP} /$ 層状ケイ酸塩（clay）コンポジットを超臨界 $\mathrm{CO}_{2}$ 雲 囲気下で溶融結晶化させることにより, 網目状あるいは フィブリル状の結晶高次構造を見出している（図 6). そ れは超臨界 $\mathrm{CO}_{2}$ 雲囲気下での伸び切りラメラ晶の形成と clay の結晶核剂効果によるものであり, clay 同士の間隔 が数十 $\mu \mathrm{m}$ と長いためにラメラスタック同士が衝突するま でにフィブリル状に結晶が成長すると考えられる。結晶化 初期に多数の結晶核が形成された後に細長い棒状の結晶に なり，それらが衝突するまでにフィブリル状に成長する様 子を超臨界顕微鏡システムにより観察している。また, clay がナノ分散した PP/clayナノコンポジットでは, PP ラメ

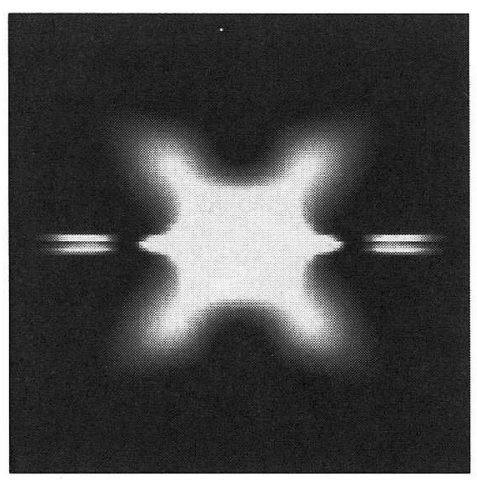

図 5 配向結晶化試料の $\mathrm{Hv}$ 光散乱像（計算結果） 
ラ晶がナノオーダーの clay の間でしか成長できないため に, 光の波長オーダーでのラメラスタック構造が形成され ず, 光学異方性のほとんどない微細結晶が形成されること がわかった。このように, clayの分散状態の違いを利用 した結晶高次構造の制御を可能にさせている。

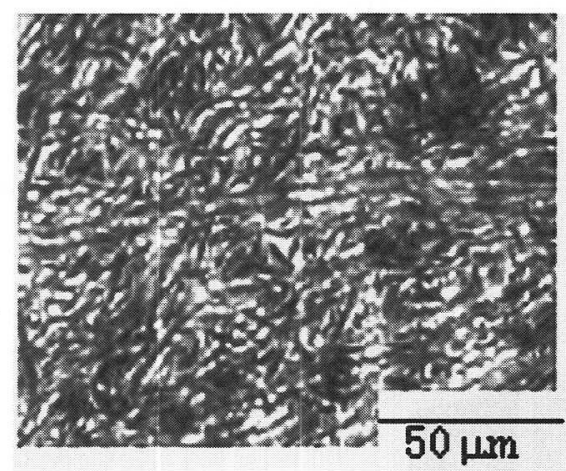

図 6 超臨界雰囲気下で得られる PP/clay のフィブリル状 結晶

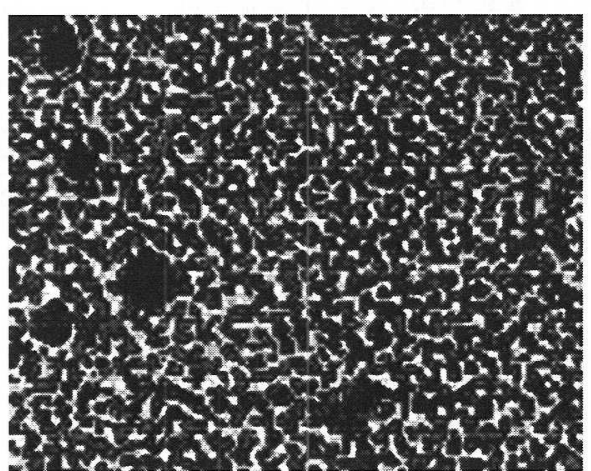

図 $7 \mathrm{PC}$ と $\mathrm{CO}_{2}$ のスピノーダル分解により得られた連結 多孔構造
$\mathrm{PC}$ を超臨界 $\mathrm{CO}_{2}$ 雾囲気下で熱処理すると, ポリカーボ ネートと超臨界 $\mathrm{CO}_{2}$ のスピノーダル分解による液々相分 離が生じることで相互連結構造が形成されることを見出し ている. 相互連結構造を急冷・急速減圧により凍結するこ とで, 連結多孔構造を得ている（図 7)。超臨界 $\mathrm{CO}_{2}$ 雲囲 気下での熱処理によりスピノーダル分解が生じることは, 超臨界光散乱システムから得られる VV 光散乱強度が時間 に対して指数関数的に増加するという Cahnの線形理論で 表されることから確認している. $140^{\circ} \mathrm{C}$ 付近ではスピノー ダル分解による連結構造が形成されるが, $180^{\circ} \mathrm{C}$ 付近の高 温では核形成・成長機構による球形の多孔構造が得ら れ， $240^{\circ} \mathrm{C}$ 以上の高温では多孔構造が消失することから， $\mathrm{PC} / \mathrm{CO}_{2}$ 系はループ型の相図を有することを明らかにして いる。このような相図を利用した多孔構造制御が今後の課 題である。また, ポリマー/無機ナノコンポジット中の無 機物による液々相分離の抑制を利用した多孔構造制御も試 みている。

これら超臨界に関する基礎科学的知見を実用面で生かす ためには超臨界場での成形加工技術の確立が今後の課題で あろう。超臨界場でのせん断, 口金からの押し出し, フィ ルム成形などの過程が観察可能な小型超臨界せん断成形装 置を試作中である。

\section{4.おわりに}

本研究室では, 研究計画から実験結果の考察に至るまで のほとんどが学生の自主性に委ねられている。市に, 上 述の研究内容は 2 年間一緒に研究を行ってきた研究室所属 学生の能力と熱意によるものである. 最後に, 山形大学の 井上隆教授, 東京農工大学の宮田清蔵学長をはじめ, 本研 究室の立ち上げにご支援頂いた方々に心から感謝致します。 